\section{Social sciences undervalued?}

\section{Washington}

OPPORTUNITIES for scientific advance in the behavioural and social sciences are being neglected, according to a new report from the US National Research Council $(\mathrm{NRC})$, the operating arm of the National Academy of Sciences.

Funding for these subjects has gone up and down like a roller coaster following a surge in the $1960 \mathrm{~s}$, but the downs have been bigger than the ups. Between 1972 and 1987 , federal support fell 25 per cent in constant dollars, while support for other areas of science rose 36 per cent.

Behavioural and social sciences encompass a huge range of research areas, from brain structure and neurotransmitters, through emotion and motivation, to the structure of human institutions, including organizations that decide science policy. The report maps the whole territory, concentrating on the areas where a push could produce rapid advance (see right).

The needed push requires human, technical and financial resources. But the resources are not there and the report complains of a "persisting view" that behavioural and social sciences research "is a virtually equipment-free enterprise" for which little more is needed than a "slightly larger office allocation". Even the tonguetwisting title of the National Science Foundation's Directorate for Biological, Behavioral and Social Sciences is thought to suggest a second-class status.

According to the report, behavioural and social scientists have almost as much need of computers as do physicists. At the behavioural end of the spectrum they make it possible to construct images of the brain from scanners; at the social end they permit the manipulation of large-scale arrays of social and economic data.

The report recommends an extra $\$ 51$ million a year for computers, neuroimaging devices and laboratory equipment. $\$ 40$ million extra per year is earmarked for the construction of large-scale databases, and $\$ 10$ million for access to government and corporation data collections.

On top of that comes a request for $\$ 44$ million to improve training at the pre- and postdoctoral level as well as at workshops; and $\$ 70$ million for individual investigator grants. A perceived need for far more interdisciplinary studies generates a request for $\$ 25$ million for new centres.

The whole bill comes to an increase of $\$ 240$ million, a 13 per cent rise on the current annual budget of $\$ 778$ million.

Alun Anderson

The Behavioral and Social Sciences: Achievements and Opportunities, is published by the National Academy Press, Washington, DC, 1988.

\title{
Yes, social sciences really do matter
}

\section{Washington}

THE NRC's report of US social sciences, even though at a coarse resolution of 23 headings, shows too many hundreds of research opportunities to try to list (see left). But with more money for parts of the behavioural and social sciences, we might know how to make the world a better place, or at least know who to blame.

People, it seems, have been doing unpleasant things to one another for a long time: the oldest archaeological evidence of organized warfare comes from a 12,000year-old cemetery in the Nile valley (see 'The evolution of human society').

More accessible to immediate analysis is criminal behaviour in the United States. Half of all urban US males can be expected to be arrested for a non-traffic offence sometime during their lives (see 'Crime and violence'). To find out why, social scientists are supplementing police reports, the traditional source of data on crime, with confidential reports from criminals about their own activities.

Both data sources confirm that a small number of 'career' criminals are responsible for a disproportionate percentage of crimes. While teenagers commit most crimes of all, the majority of them stop offending after adolescence. Career criminals continue through their 30 s or sometimes even 40s.

What determines when people abandon crime? And how are criminal careers affected by punishment? Is it worth imprisoning some young criminals for long periods when their careers may soon come to a natural end anyway? Finding the answers to these questions requires large-scale surveys with overlapping cohorts of subjects. And that is expensive.

Some would like to blame everything on modernization and the concomitant decline of the extended family: analysis of historical archives is turning this view upside down (see 'Modernization: family and religion'). It seems that the nuclear family emerged at the closing of the middle ages and provided the independent people who originated the industrial revolution, rather than being its result.

\section{International SSC funding causes scepticism in Congress}

\section{Washington}

The Department of Energy (DoE) anxious to find ways to persuade a financially tight-fisted Congress to commit to the expensive Superconducting Super Collider (SSC) - has promised that governments all over the world are enthusiastic about the project, and might contribute as much as half the estimated $\$ 4,400$ million cost of building it. But a congressional committee last week said that DoE's promises must be backed up by firm commitments, not good intentions.

James Decker, acting director of energy research, appeared before the international scientific cooperation subcommittee of the House of Representatives Committee on Science, Space and Technology to describe the interest other countries have in SSC.

In January, Decker and George Bradley, principal deputy assistant secretary, between them have visited Italy, France, the United Kingdom, West Germany, Switzerland, Canada and Japan, as well as CERN (the European laboratory for particle physics). Decker described these visits as extremely cordial, saying there was great enthusiasm for SSC, especially among physicists.

But under questioning from committee members, Decker was unable to describe any firm commitments to SSC. In budget documents delivered to Congress in February, DoE indicated that it expected foreign contributions, both cash and "in- kind", to amount to $\$ 1,800$ million, but Decker was unable to offer much explanation about how the figure was reached. Part of the $\$ 1,800$ million is expected to come from financial packages put together by the state that wins the competition to be the home for SSC.

A classic Catch-22 predicament is in danger of developing with respect to international participation in SSC. DoE argues that a strong financial commitment from Congress - in the form of a hefty appropriation - will convince other countries that the United States is serious about the project. But Congress, wary of empty promises, has given notice that it wants a substantive show of support before committing itself. In testimony to Congress two weeks ago, Energy Secretary James Herrington said that foreign participation could amount to as much as 50 per cent of the cost, but Decker told the committee he thought 40 per cent was a more reasonable high-end figure.

For their part, the committee members seemed unconvinced by Decker's rosy evaluation of the situation. Representative Robert Roe (Democrat, New Jersey) said SSC had entered the "real world", and its supporters would have to provide realistic budget estimates if the plan was to be sold to the entire Congress. Roe also warned that foreign scientists might be prohibited from using SSC is their governments did not contribute to the cost of its construction. 